\title{
Maternal transfer of contaminants in birds: mercury and selenium concentrations in parents and their eggs
}

\author{
Joshua T. Ackerman, ${ }^{\mathrm{a}, *}$ Collin A. Eagles-Smith, ${ }^{\mathrm{b}}$ Mark P. Herzog, ${ }^{\mathrm{a}}$ and C. Alex Hartman ${ }^{\mathrm{a}}$ \\ ${ }^{a}$ U.S. Geological Survey, Western Ecological Research Center, Dixon Field Station, 800 Business Park \\ Drive, Suite D, Dixon, California 95620, United States \\ ${ }^{\mathrm{b}}$ U.S. Geological Survey, Forest and Rangeland Ecosystem Science Center, 3200 SW Jefferson Way, \\ Corvallis Oregon, 97331, United States
}

Word Count: 5,933; with 4 figures

*Corresponding Author

December 7, 2015 


\section{ABSTRACT}

We conducted a detailed assessment of the maternal transfer of mercury and selenium to eggs in three bird species ( $n=107$ parents and $n=339$ eggs), and developed predictive equations linking contaminant concentrations in eggs to those in six tissues of the mother (blood, muscle, liver, kidney, breast feathers, and head feathers). Mercury concentrations in eggs were positively correlated with mercury concentrations in each of the mother's internal tissues $\left(R^{2} \geq 0.95\right)$, but generally not with feathers. For each species, the proportion of mercury transferred to eggs decreased as mercury concentrations in the mother increased. At the same maternal mercury concentration, the proportion of mercury transferred to eggs differed among species, such that Forster's tern (Sterna forsteri) and blacknecked stilt (Himantopus mexicanus) females transferred more methylmercury to their eggs than American avocet (Recurvirostra americana) females. Selenium concentrations in eggs also were correlated with selenium concentrations in the mother's liver $\left(R^{2}=0.87\right)$. Furthermore, mercury and selenium concentrations in tern eggs were positively correlated with those in the father $\left(R^{2}=0.84\right)$. Incubating male terns had 21\% higher mercury concentrations in blood compared to incubating females at the same egg mercury concentration. We provide equations to predict contaminant concentrations in eggs from each of the commonly sampled bird tissues.

\section{Key Words}

Birds, Eggs, Mercury, Selenium, Maternal Transfer

\section{Capsule}

We examined the maternal transfer of mercury and selenium to eggs in three bird species, and developed predictive equations linking contaminant concentrations in eggs and mothers.

\section{Introduction}

Methylmercury contamination of the environment is widespread globally (Driscoll et al., 2013), and methylmercury biomagnifies primarily through aquatic food chains (Wiener et al., 2003) where environmental conditions tend to be conducive to methylmercury production (Ullrich et al., 2001). Birds often are vulnerable to mercury contamination because they are top predators in many aquatic habitats (Scheuhammer et al., 2007), and mercury has long been a primary contaminant of concern for birds (Bond et al., 2015; Monteiro et al., 1997). Because reproduction is among the most sensitive end points for mercury toxicity in birds (Scheuhammer et al., 2007; Wiener et al., 2003), eggs are considered an ideal sampling tissue for evaluating mercury exposure and potential toxicity to birds (Hartman et al., 2013). However, many different bird tissues are commonly sampled to assess mercury exposure (Scheuhammer et al., 2007; Wiener et al., 2003), and often it is difficult to compare mercury concentrations in adult bird tissues to the more highly developed toxicity benchmarks established for eggs (Braune et al., 2012; Heinz et al., 2009b; Kenow et al., 2011). Thus, quantifying the relationship between mercury concentrations, and other contaminants, in parental tissues and their eggs would allow conversion of contaminant concentrations in female tissues to those expected to be in her eggs.

Several prior studies have examined the relationship between mercury concentrations in mothers and her eggs. Lewis et al. (1993) found weak correlations between mercury concentrations in the first egg laid by herring gulls (Larus argentatus) and those in the incubating female's liver $\left(R^{2}=0.18\right)$ and muscle $\left(R^{2}=0.12\right)$, but not those in the ovary $\left(R^{2}=0.06\right)$ or feathers $\left(R^{2}<0.01\right)$. Evers et al. (2003) observed a stronger relationship $\left(R^{2}=0.79\right)$ between mercury concentrations in nonviable, abandoned eggs and those in the blood of female common loons (Gavia immer) that were captured within the same territory in either the specific year or in a different year than when the eggs were collected. Kenow et al. (2015) found an even stronger correlation $\left(R^{2}=0.97\right)$ between both the first and second laid egg's 
mercury concentration and those in the blood of female common loons that were captured on the nest within a few days of when the eggs were laid. Brasso et al. (2010) also documented a correlation $\left(R^{2}=0.87\right)$ between the mean mercury concentration in a clutch and those in the blood of female tree swallows (Tachycineta bicolor) that were captured at the nest soon after the full clutch was laid. Heinz et al. (Heinz et al., 2010) fed captive mallards (Anas platyrhynchos) a diet containing methylmercury chloride and established a strong relationship between mercury concentrations in a single egg and blood of the female that was bled either the same day the egg was laid $\left(R^{2}=0.88\right)$ or bled $16-27$ days after the egg was laid $\left(R^{2}=0.67\right)$. Ou et al. (2015) fed captive zebra finches (Taeniopygia guttata) a diet dosed with methylmercury cysteine and also observed a strong relationship between mean mercury concentrations in a clutch and those in the female's blood $\left(R^{2}=0.93\right)$. These results indicate that there likely is a strong relationship between mercury concentrations in females and her eggs, however each study focused on a single species, used a limited number of parental tissues, and had various methodological differences which make it difficult to broadly apply these relationships to birds.

We conducted a detailed assessment of the maternal transfer of mercury to eggs in three species of birds. Because selenium can influence mercury dynamics in birds (Eagles-Smith et al., 2009b; Henny et al., 2002), we also evaluated maternal transfer of selenium to eggs. We selected species that were known to have relatively high (Forster's terns, Sterna forsteri; hereafter referred to as terns), moderate (black-necked stilts, Himantopus mexicanus; hereafter referred to as stilts), and low (American avocets, Recurvirostra americana; hereafter referred to as avocets) exposure to mercury (Ackerman et al., 2013b; Eagles-Smith et al., 2009a) which allowed us to examine maternal transfer of contaminants over a wide range of exposure levels. These species also represented different foraging guilds, with tern diets consisting mainly of fish (McNicholl et al., 2001) and avocet and stilt diets consisting mainly of aquatic invertebrates (Ackerman et al., 2013a; Robinson et al., 1999). We developed predictive equations to link mercury and selenium concentrations in eggs to concentrations in six tissues of the mother (blood, muscle, liver, kidney, breast feathers, and head feathers). We also related mercury and selenium concentrations in eggs to concentrations in the father's blood and liver, respectively, to assess whether mates had similar contamination levels.

\section{Material and Methods}

\subsection{Sample collection}

During 2005 and 2006, we collected breeding avocets, stilts, and terns at several locations throughout San Francisco Bay, California $\left(37.8^{\circ} \mathrm{N}, 122.3^{\circ} \mathrm{W}\right)$. Capture methods are described in detail elsewhere (Eagles-Smith et al., 2008), as these bird collections were used to investigate several topics related to contaminants in birds (Ackerman and Eagles-Smith, 2009; Eagles-Smith et al., 2009a, 2009b, 2008; Herring et al., 2010; Hoffman et al., 2011). Briefly, we collected avocets, stilts, and terns on their nests during early incubation (Eagles-Smith et al., 2008), after we had confirmed during our routine nest monitoring procedures (Ackerman et al., 2014) that their nests contained a full clutch of eggs and were being incubated normally. Overall, $87 \%$ of birds were collected before the mid-point of the incubation period as determined by egg flotation (Ackerman and Eagles-Smith, 2010). Nesting birds were collected using self-triggered treadle traps, remotely activated bow nets (Northwoods, Rainer, Washington, USA), or net launchers (Coda Enterprises, Mesa, Arizona, USA). Once the parent was captured, we collected all eggs in the clutch and stored them in a refrigerator until egg dissection. Because both sexes incubate eggs in these three species, we waited until we observed the female return to the target nest before setting the nest trap. We used plumage coloration to identify female stilts (Robinson et al., 1999) and bill shape to identify female avocets (Ackerman et al., 2013a). The sex of Forster's terns cannot be easily determined in the field (Bluso et al., 2006), therefore we collected the 
incubating parent (male or female) and determined sex during necropsy and genetic analysis (Zoogen Services, Davis, California, USA).

\subsection{Egg dissection and adult necropsy}

Prior to egg dissection, we allowed refrigerated eggs to come to room temperature and then we measured egg length and width to the nearest $0.01 \mathrm{~mm}$ using digital calipers (Fowler, Newton, Massachusetts, USA) and total egg weight (with eggshell) to the nearest $0.01 \mathrm{~g}$ on a digital balance (Ohaus Adventurer Pro, Ohaus Corporation, Pine Brook, New Jersey, USA). Using clean, stainless steel instruments, we cut a $15 \mathrm{~mm}$ diameter hole in the wide end of each egg and removed the entire egg contents into a tared, sterile 30 or $60 \mathrm{~mL}$ jar. We then measured egg content weight (without eggshell) with a digital balance to the nearest $0.01 \mathrm{~g}$, and stored egg contents at $-20^{\circ} \mathrm{C}$ until processing and mercury and selenium determination.

Following bird collection, we sampled whole blood from each bird using sodium-heparinized 23-25 gauge needles attached to polypropylene syringes, and then transferred the blood to polypropylene cryovials. Whole blood was collected either via the brachial vein prior to, or from the heart during, necropsy (Eagles-Smith et al., 2008). We also collected fully grown breast feathers from the anterior area of the keel and head feathers from the crown. We then conducted necropsies on each bird using clean, acid-rinsed, and stainless-steel instruments to excise the liver, kidneys, and a portion of breast muscle. We placed tissue samples in I-CHEM glass vials (Chase Scientific Glass, Rockwood, Tennesse, USA) or Whirl-Paks ${ }^{\circledR}$ (Nasco, Modesto, California, USA). All tissue samples were stored on dry ice in the field and at $-20^{\circ} \mathrm{C}$ in the laboratory until processing and mercury determination.

\subsection{Sample processing}

We thawed egg samples at room temperature, and then dried the entire egg contents at $50^{\circ} \mathrm{C}$ for $48 \mathrm{~h}$ or until completely dried. To determine moisture content, we reweighed dried egg contents with a digital balance to the nearest $0.0001 \mathrm{~g}$ (Ohaus Adventurer Balance, model AR064; Ohaus, Pine Brook, New Jersey, USA). We then ground the dried egg contents to a powder using a spice grinder with stainless steel blades, followed by further grinding by hand in a mortar and pestle. We thawed liver, kidney, and muscle samples at room temperature, rinsed them in deionized water, and blotted them dry with Kimwipes ${ }^{\circledR}$ (Kimberly-Clark, Roswell, Georgia, USA). We measured each tissue’s wet mass and then oven-dried them at $50^{\circ} \mathrm{C}$ for $48 \mathrm{~h}$ or until they reached a constant mass $(0.0001 \mathrm{~g}$; Ohaus Adventurer Balance, model AR064; Ohaus, Pine Brook, New Jersey, USA). We then homogenized each tissue sample separately using a porcelain mortar and pestle. We washed and manually scrubbed feathers in a 1\% Alconox solution (Alconox, White Plains, New York, USA) to remove surface debris, and then oven-dried them at $50^{\circ} \mathrm{C}$ for $24 \mathrm{~h}$. We stored the processed and dried tissue samples in a desiccator until mercury determination. We thawed blood to room temperature, inverted the cryovials several times, and thoroughly mixed the blood by stirring with a clean pipette tip to ensure sample homogeneity before mercury determination. Some blood samples that were high in mercury were further diluted with deionized water before mercury determination (Ackerman et al., 2008; EaglesSmith et al., 2008).

\subsection{Mercury determination}

We determined total mercury (THg) concentrations in all tissues, and used it as an index of methylmercury (MeHg) concentrations because $96 \%$ and $\geq 90 \%$ of the THg in bird eggs and blood, respectively, is in the more toxic MeHg form (Ackerman et al., 2013b; Rimmer et al., 2005). However, we also determined MeHg concentrations in liver and kidney, because a smaller proportion of THg in those tissues can be in the inorganic form (as low as 20\% MeHg; Eagles-Smith et al., 2009b). We 
determined THg concentrations in whole blood, egg contents (without the eggshell), muscle, liver, kidney, and feathers on a Milestone DMA-80 Direct Mercury Analyzer (Milestone, Monroe, Connecticut, USA) following Environmental Protection Agency Method 7473 (U.S. Environmental Protection Agency, 2000), using an integrated sequence of drying, thermal decomposition, catalytic conversion, and then amalgamation, followed by atomic absorption spectroscopy. We determined MeHg concentrations in liver and kidney samples at Battelle Marine Sciences Laboratory (Sequim, Washington, USA) using cold vapor atomic fluorescence following Environmental Protection Agency Method 1630 (U.S. Environmental Protection Agency, 2001).

We report THg concentrations on a dry-weight ( $\mathrm{dw}$ ) basis for most bird tissues, except blood which we report on a wet-weight (ww) basis and eggs which we report on a fresh wet-weight basis (fww). THg concentrations in eggs were determined on a dry weight basis and then converted into a fresh wet weight egg concentration using individual-specific moisture content of the egg contents and egg morphometrics following the methods of Ackerman et al. (2013b) and egg densities specific to these bird species (authors, unpublished). Moisture content (mean \pm SE) was $73.6 \% \pm 0.3 \%$ in bird eggs, $69.7 \% \pm 0.1 \%$ in muscle, $67.0 \% \pm 0.2 \%$ in liver, and $73.6 \% \pm 0.1 \%$ in kidney.

Quality assurance measures included analyses of at least two certified reference materials (either dogfish muscle tissue [DORM], dogfish liver [DOLT], or lobster hepatopancreas [TORT] certified by the National Research Council of Canada, Ottawa, Canada), two system and method blanks, three continuing calibration verifications, two duplicates, and two spiked duplicates per batch. Recoveries for certified reference materials averaged $107.0 \pm 1.1 \%(n=59)$ for eggs and $102.1 \pm 0.9 \%(n=329)$ for adult tissues. Recoveries for calibration verifications averaged 101.0 $\pm 0.5 \%(n=140)$ for eggs and $99.9 \pm 0.7 \%$ $(n=409)$ for adult tissues. Matrix spike recoveries averaged $101.0 \pm 0.8 \%(n=96)$ for eggs and $97.7 \pm 1.3 \%$ $(n=154)$ for adult tissues. Relative percent difference (RPD) for duplicates averaged $6.1 \pm 0.6 \%(n=87)$ for eggs and $7.8 \pm 1.9 \%(n=278)$ for adult tissues, and RPD for matrix spike duplicates averaged $4.4 \pm 0.7 \%(n=48)$ for eggs and 5.0 $\pm 1.0 \%(n=154)$ for adult tissues. Recoveries for MeHg in adult tissues averaged $106.2 \pm 1.83 \%(n=57)$ for certified reference materials and $96.8 \pm 1.83 \%(n=175)$ for matrix spikes. RPD for duplicate MeHg samples averaged 7.8 $\pm 1.5 \%(n=42)$ and RPD for matrix spike duplicates averaged $7.3 \pm 1.3 \%(n=87)$.

\subsection{Selenium determination}

We determined selenium (Se) concentrations in a randomly selected subset $(n=43)$ of parent liver samples and in each of the individual eggs in their clutch at Trace Elements Research Laboratory (Texas A\&M University, College Station, TX, USA) using hydride generation followed by atomic fluorescence. Certified reference materials for Se in tissues (National Institute of Standards and Technology 2976), matrix spikes, duplicate samples, and blanks were analyzed for quality-control purposes. For livers, recoveries for certified reference materials averaged $106.3 \% \pm 3.1 \%(n=11)$, matrix spikes averaged 102.0\% $\pm 7.0 \%(n=11)$, and RPD for duplicates averaged $3.8 \% \pm 1.2 \%(n=11)$. For eggs, recoveries for certified reference materials averaged 98.5\% $\pm 3.3 \%(n=49)$, matrix spikes averaged $99.2 \% \pm 3.7 \%(n=98)$, and RPD for duplicates averaged $3.4 \% \pm 3.3 \%(n=98)$.

\subsection{Statistical analysis}

We used linear mixed-effects models to examine the relationship between THg concentrations in parents and their eggs. All THg, MeHg, and Se concentrations were loge-transformed to improve normality. We conducted separate analyses for each of the eight Hg concentrations measured in parents, including 6 tissues (blood, muscle, liver, kidney, breast feathers, and head feathers) and two forms of $\mathrm{Hg}$ (THg and MeHg). THg or MeHg concentration in individual eggs was the dependent variable and female tissue Hg concentration and species (avocet, stilt, or tern) were fixed effects, female 
tissue Hg concentration $\times$ species was included as an interaction, and nest identification was a random effect. This model structure statistically nested individual eggs within their clutch. In seven of the eight models (excluding the head feather model), the interaction for female tissue $\mathrm{Hg}$ concentration $\times$ species was not significant and was dropped from the final model. Because we only sampled males in a single species, we conducted an additional analysis for terns where THg concentration in individual eggs was the dependent variable and tissue Hg concentration and sex (male or female) were fixed effects, parent tissue $\mathrm{Hg}$ concentration $\times$ sex was included as an interaction, and nest identification was a random effect. The interaction for tissue Hg concentration $\times$ sex was not significant and was dropped from the final model.

We also used linear mixed-effects models to examine the relationship between Se concentrations in a subset of parents and their eggs. Se concentration in individual eggs was the dependent variable and female liver Se concentration and species were fixed effects, female liver Se concentration $\times$ species was included as an interaction, and nest identification was a random effect. Additionally for terns, we conducted an analysis where Se concentration in individual eggs was the dependent variable and liver Se concentration and sex were fixed effects, parent liver Hg concentration $\times$ sex was included as an interaction, and nest identification was a random effect. In both models for Se concentrations, the interactions for either liver Se concentration $\times$ species or liver Se concentration $\times$ sex were not significant and were dropped from the final models.

In the figures, we present the clutch's geometric mean contaminant concentration in eggs and the range of contaminant concentrations in individual eggs within the clutch versus the parent's tissue contaminant concentration. We report back-transformed least squares means and estimated standard errors using the delta method (Seber, 1982).

\section{Results}

We collected 107 parents and their clutches ( $n=339$ eggs), including 30 female avocets, 32 female stilts, 21 female terns, and 24 male terns. Geometric mean THg concentrations within clutches averaged $0.38 \mu \mathrm{g} / \mathrm{g}$ fww in avocets $(n=30), 0.67 \mu \mathrm{g} / \mathrm{g}$ fww in stilts $(n=32)$, and $1.23 \mu \mathrm{g} / \mathrm{g}$ fww in terns ( $n=45$ ), and individual eggs ranged from 0.02 to $1.62 \mu \mathrm{g} / \mathrm{g}$ fww in avocets $(n=104), 0.16$ to $3.74 \mu \mathrm{g} / \mathrm{g}$ fww in stilts $(n=111)$, and 0.40 to $3.37 \mu \mathrm{g} / \mathrm{g}$ fww in terns $(n=124)$. Geometric mean Se concentrations within clutches averaged $0.48 \mu \mathrm{g} / \mathrm{g}$ fww in avocets $(n=10), 0.37 \mu \mathrm{g} / \mathrm{g}$ fww in stilts $(n=10)$, and 0.52 $\mu \mathrm{g} / \mathrm{g}$ fww in terns $(n=26)$, and individual eggs ranged from 0.21 to $0.74 \mu \mathrm{g} / \mathrm{g}$ fww in avocets $(n=36)$, 0.25 to $0.53 \mu \mathrm{g} / \mathrm{g}$ fww in stilts $(n=36)$, and 0.34 to $0.84 \mu \mathrm{g} / \mathrm{g}$ fww in terns $(n=70)$.

\subsection{Female blood to egg mercury correlations}

THg concentrations in eggs were positively correlated with THg concentrations in the mother's blood $\left(F_{1,71.10}=180.93, p<0.0001\right.$, Figure 1a), while accounting for the influence of species $\left(F_{2,72.79}=3.81, p=0.03\right)$. The overall model's fit to the data was high $\left(n=251\right.$ eggs, $\left.R^{2}=0.95\right)$, indicating that the transfer of MeHg from adults to offspring was highly predictable (Figure 1a). The significant main effect of species, but non-significant interaction between blood THg concentrations $\times$ species $\left(F_{2,71.44}=1.27, p=0.29\right)$, indicated that the relationship between THg concentrations in eggs and female blood had different intercepts but similar slopes (Figure 1a). Therefore, equations to predict THg concentrations in eggs from THg concentrations in female blood were different between species. The specific equations to predict THg concentrations in eggs from THg concentrations in female blood were: 
(1) $\ln \left(\right.$ Egg THg $\left.g_{\frac{\mu g}{g} f w w}\right)=0.8461 \times \ln \left(\right.$ Female Tern Blood THg $\left.\frac{\mu g}{g} w w_{w}\right)-0.5951$

(2) $\ln \left(\right.$ Egg THg $\left.\frac{\mu g}{g} f w w\right)=0.8461 \times \ln \left(\right.$ Female Avocet Blood THg $\left.\frac{\mu g}{g} w w\right)-0.9381$

(3) $\ln \left(\right.$ Egg THg $\left.\frac{\mu g}{g} f w w\right)=0.8461 \times \ln \left(\right.$ Female Stilt Blood THg $\left.\frac{\mu g}{g} w w\right)-0.7002$

Because of the utility of a more general equation across species to predict THg concentrations in eggs from THg concentrations in female bird blood, we produced a model that excluded the species effect. Although this general bird model had a steeper slope than the species-specific models, model fit was still very high ( $n=251$ eggs, $\left.R^{2}=0.95\right)$ :

(4) $\ln \left(\right.$ Egg THg $\left.\frac{\mu g}{g} f w w\right)=0.9316 \times \ln \left(\right.$ Female Bird Blood THg $\left.\frac{\mu g}{g} w w\right)-0.75914$

\subsection{Female muscle to egg mercury correlations}

THg concentrations in eggs were positively correlated with THg concentrations in the mother's breast muscle $\left(F_{1,78.11}=330.29, p<0.0001\right.$; Figure $\left.1 \mathbf{b}\right)$, while accounting for the influence of species $\left(F_{2,79.80}=18.70, p<0.0001\right)$. There was no interaction between muscle THg concentrations $\times$ species $\left(F_{2,78.50}=0.25, p=0.78\right)$. The model's fit was high $\left(n=270\right.$ eggs, $\left.R^{2}=0.96\right)$ and the equations to predict THg concentrations in eggs from THg concentrations in female muscle were:

(5) $\ln \left(E g g\right.$ THg $\left.\frac{\mu g}{g} f w w\right)=0.9534 \times \ln \left(\right.$ Female Tern Muscle THg $\left.\frac{\mu g}{g} d w\right)-1.3304$

(6) $\ln \left(\right.$ Egg THg $\left.\frac{\mu g}{g} f w w\right)=0.9534 \times \ln \left(\right.$ Female Avocet Muscle THg $\left.\frac{\mu g}{g} d w\right)-1.9806$

(7) $\ln \left(\right.$ Egg THg $\left.\frac{\mu g}{g} f w w\right)=0.9534 \times \ln \left(\right.$ Female Stilt Muscle THg $\left.\frac{\mu g}{g} d w\right)-1.6468$

\subsection{Female liver to egg mercury correlations}

THg concentrations in eggs were positively correlated with both THg and MeHg concentrations in the mother's liver (THg: $F_{1,78.06}=284.65, p<0.0001$, Figure 1c; MeHg: $F_{1,77.43}=224.39, p<0.0001$, Figure 1d), while accounting for the influence of species (THg: $F_{2,79.76}=10.34, p=0.0001$; MeHg: $\left.F_{2,78.90}=5.56, p=0.01\right)$. There was no interaction between liver THg or MeHg concentrations $\times$ species (THg: $F_{2,77.37}=0.48, p=0.62$; MeHg: $F_{2,76.83}=0.36, p=0.70$ ). The models' fits were high (THg: $n=270$ eggs, $R^{2}=0.96$; MeHg: $n=268$ eggs, $R^{2}=0.96$ ), and the equations to predict THg concentrations in eggs from THg or MeHg concentrations in female liver were:

(8) $\ln \left(E g g T H g_{\frac{\mu g}{g} f w w}\right)=0.8991 \times \ln \left(\right.$ Female Tern Liver THg $\left.\frac{\mu g}{g} d w\right)-2.2156$

(9) $\ln \left(\right.$ Egg THg $\left.\frac{\mu g}{g} f w w\right)=0.8991 \times \ln \left(\right.$ Female Avocet Liver THg $\left.\frac{\mu g}{g} d w\right)-2.7465$

(10) $\ln \left(E g g T H g \frac{\mu g}{g} f w w\right)=0.8991 \times \ln \left(\right.$ Female Stilt Liver THg $\left.\frac{\mu g}{g} d w\right)-2.4922$

(11) $\ln \left(E g g\right.$ THg $\left.\frac{\mu g}{g} f w w\right)=0.9387 \times \ln \left(\right.$ Female Tern Liver MeHg $\left.\frac{\mu g}{g} d w\right)-2.2039$

(12) $\ln \left(E g g T H g \frac{\mu g}{g} f w w\right)=0.9387 \times \ln \left(\right.$ Female Avocet Liver MeHg $\left.\frac{\mu g}{g} d w\right)-2.6371$

(13) $\ln \left(E g g T H g \frac{\mu g}{g} f w w\right)=0.9387 \times \ln \left(\right.$ Female Stilt Liver MeHg $\left.\frac{\mu g}{g} d w\right)-2.3953$ 


\subsection{Female kidney to egg mercury correlations}

THg concentrations in eggs were positively correlated with THg and MeHg concentrations in the mother's kidney (THg: $F_{1,76.51}=315.72, p<0.0001$, Figure 1e; MeHg: $F_{1,77.87}=221.31, p<0.0001$, Figure 1f), while accounting for species (THg: $F_{2,78.53}=4.82, p=0.01$; $\mathrm{MeHg}: F_{2,79.01}=2.22, p=0.12$ ). There was no interaction between kidney THg or MeHg concentrations $\times$ species $\left(\mathrm{THg}: F_{2,77.11}=0.88, p=0.42\right.$; MeHg: $F_{2,77.71}=0.20, p=0.82$ ). The models' fits were high (THg: $n=270$ eggs, $R^{2}=0.96$; MeHg: $n=268$ eggs, $R^{2}=0.96$ ), and the equations to predict THg concentrations in eggs from $\mathrm{THg}$ or $\mathrm{MeHg}$ concentrations in female kidney were:

(14) $\ln \left(E g g\right.$ THg $\left.\frac{\mu g}{g} f w w\right)=0.9397 \times \ln \left(\right.$ Female Tern Kidney THg $\left.\frac{\mu g}{g} d w\right)-2.4465$

(15) $\ln \left(E g g T H g \frac{\mu g}{g} f w w\right)=0.9397 \times \ln \left(\right.$ Female Avocet Kidney THg $\left.\frac{\mu g}{g} d w\right)-2.7180$

(16) $\ln \left(E g g T H g \frac{\mu g}{g} f w w\right)=0.9397 \times \ln \left(\right.$ Female Stilt Kidney $\left.T H g \frac{\mu g}{g} d w\right)-2.4423$

(17) $\ln \left(E g g\right.$ THg $\left.\frac{\mu g}{g} f w w\right)=0.9121 \times \ln \left(\right.$ Female Tern Kidney MeHg $\left.\frac{\mu g}{g} d w\right)-2.1987$

(18) $\ln \left(\right.$ Egg THg $\left.\frac{\mu g}{g} f w w\right)=0.9121 \times \ln \left(\right.$ Female Avocet Kidney MeHg $\left.\frac{\mu g}{g} d w\right)-2.4123$

(19) $\ln \left(\right.$ Egg THg $\left.\frac{\mu g}{g} f w w\right)=0.9121 \times \ln \left(\right.$ Female Stilt Kidney MeHg $\left.\frac{\mu g}{g} d w\right)-2.1922$

\subsection{Female feather to egg mercury correlations}

THg concentrations in eggs were positively correlated with THg concentrations in the mother's head feathers $\left(F_{1,75.87}=70.22, p<0.0001\right.$, Figure $\left.2 a\right)$, but not breast feathers $\left(F_{1,79.51}=2.91, p=0.09\right.$, Figure 2b), while accounting for the influence of species in each model (breast feather: $F_{2,79.39}=10.59$, $p<0.0001$; head feather: $\left.F_{2,75.23}=38.36, p<0.0001\right)$. There was a significant interaction between head feather THg concentrations $\times$ species $\left(F_{2,75.96}=27.01, p<0.0001\right)$, but not breast feather THg concentrations $\times$ species $\left(F_{2,77.22}=2.27, p=0.11\right)$, indicating that the relationship between $\mathrm{THg}$ concentrations in eggs and the mother's head feathers differed among species. Indeed, THg concentrations in eggs and head feathers were positively correlated for avocets and stilts, but not for terns (Figure 2a). In contrast, THg concentrations in eggs and breast feathers were not correlated for any species (Figure $2 \mathbf{b})$. The head feather model's fit was high $\left(n=262\right.$ eggs, $\left.R^{2}=0.96\right)$, and the equations to predict THg concentrations in eggs from THg concentrations in female head feathers were:

(20) $\ln \left(\right.$ Egg THg $\left.\frac{\mu g}{g} f w w\right)=-0.0404 \times \ln \left(\right.$ Female Tern Head Feather THg $\left.\frac{\mu g}{g} d w\right)+0.0864$

(21) $\ln \left(\right.$ Egg THg $\left.\frac{\mu g}{g} f w w\right)=1.0391 \times \ln \left(\right.$ Female Avocet Head Feather THg $\left.\frac{\mu g}{g} d w\right)-3.2672$

(22) $\ln \left(\right.$ Egg THg $\left.\frac{\mu g}{g} f w w\right)=0.8608 \times \ln \left(\right.$ Female Stilt Head Feather THg $\left.\frac{\mu g}{g} d w\right)-2.8994$

\subsection{Female liver to egg selenium correlations}

Se concentrations in eggs were correlated with Se concentrations in the mother's liver $\left(F_{1,29.06}=16.72, p=0.001\right.$, Figure 3$)$, while accounting for the influence of species $\left(F_{2,28.89}=5.16, p=0.01\right)$. There was no interaction between liver Se concentrations $\times$ species $\left(F_{2,27.20}=2.17, p=0.13\right)$. The model's fit for Se was lower ( $n=107$ eggs, $\left.R^{2}=0.87\right)$ than the fit for THg $\left(n=270\right.$ eggs, $\left.R^{2}=0.96\right)$. The equations to predict Se concentrations in eggs from Se concentrations in female liver were: 
(23) $\ln \left(\right.$ Egg Se $\left.\frac{\mu g}{g} f w w\right)=0.6136 \times \ln \left(\right.$ Female Tern Liver Se $\left.\frac{\mu g}{g} d w\right)-1.7482$

(24) $\ln \left(\right.$ Egg Se $\left.\frac{\mu g}{g} f w w\right)=0.6136 \times \ln \left(\right.$ Female Avocet Liver Se $\left.\frac{\mu g}{g} d w\right)-1.8638$

$$
\ln \left(\text { Egg Se } \frac{\mu g}{g} f w w\right)=0.6136 \times \ln \left(\text { Female Stilt Liver Se } \frac{\mu g}{g} d w\right)-1.9913
$$

\subsection{Male blood to egg mercury correlations}

Because we could not differentiate female and male terns in the field, we also happened to sample male terns. We therefore conducted a separate analysis of the relationship between tern parents (males and females) and their eggs. THg concentrations in eggs were positively correlated with THg concentrations in the father's blood $\left(F_{1,38.07}=29.06, p<0.0001\right.$, Figure 4a), while accounting for the influence of sex $\left(F_{1,37.84}=3.64, p=0.06\right)$. The overall model's fit to the data for terns was relatively high ( $n=105$ eggs, $R^{2}=0.84$ ). The near significant main effect of sex, but non-significant interaction between blood THg concentrations $\times \operatorname{sex}\left(F_{1,36.88}=0.19, p=0.67\right)$, indicated that the relationship between THg concentrations in eggs and parents' blood had different intercepts but similar slopes between sexes (Figure 4a). Based on the model estimated intercept, incubating male terns had 21\% higher THg concentrations in blood compared to incubating female terns at the same egg THg concentration.

\subsection{Male liver to egg selenium correlations}

Se concentrations in eggs also were correlated with Se concentrations in the father's liver $\left(F_{1,22.32}=10.99, p=0.01\right.$, Figure $\left.4 \mathbf{b}\right)$, while accounting for sex $\left(F_{1,22.21}=0.42, p=0.52\right)$. The overall model's fit to the data was relatively high $\left(n=67\right.$ eggs, $\left.R^{2}=0.86\right)$. The non-significant effects of sex and liver Se concentration $\times$ sex interaction $\left(F_{1,20.72}=1.85, p=0.19\right)$, indicated that the correlation between Se concentrations in eggs and adult liver had similar intercepts and slopes between sexes (Figure $4 \mathbf{b}$ ).

\section{Discussion}

Hg concentrations in eggs were positively correlated with Hg concentrations in each of the four internal tissues of the mother (Figure 1), indicating that MeHg in mothers is transferred to offspring in a predictable way. Because the slopes for each of the log-log regressions were $<1$, the proportion of $\mathrm{Hg}$ transferred to offspring decreased as Hg concentrations in the mother increased. Thus, a smaller proportion of the mother's Hg was transferred to eggs at higher maternal Hg concentrations. Further, the slopes of the regressions were similar among species, suggesting that the reduction in the maternal transfer coefficient with increasing maternal Hg concentrations did not differ among species. In contrast, the intercepts differed among species such that, at the same maternal Hg concentration, the proportion of $\mathrm{Hg}$ transferred to offspring differed among species. In particular, tern and stilt females transferred slightly more MeHg to their eggs than did avocet females at equivalent maternal Hg concentrations.

Se concentrations in eggs also were correlated with Se concentrations in the mother's liver (Figure 3), although the correlation between contaminant concentrations in parents and their eggs were stronger for $\mathrm{Hg}\left(R^{2}=0.96\right)$ than for Se $\left(R^{2}=0.87\right)$. The slope for the correlation between Se concentrations in eggs and the mother's liver (0.61) was much lower than for the correlation between Hg concentrations in eggs and the mother's liver (THg: 0.90, MeHg: 0.94), indicating that the proportion of the contaminant transferred to offspring decreased more for Se than for $\mathrm{Hg}$ as the corresponding contaminant concentration in the mother's liver increased. These results indicate that maternal transfer coefficients differ among contaminants and species, and vary with the overall 
contaminant concentration in the mother. The mechanism which could cause this difference in maternal transfer coefficients among contaminants is unclear.

In contrast to internal tissues, feathers were generally poor predictors of THg concentrations in bird eggs, as was found by Lewis et al. (1993), but there were some exceptions. In particular, the mother's breast feathers were unrelated to her egg THg concentrations in each of the three species (Figure 2b). Head feathers, on the other hand, could be related to egg THg concentrations, but it depended on the species (Figure 2a). Mothers' head feathers were strongly correlated with their egg THg concentrations in avocets and stilts, whereas there was no relationship in terns. These results align with our prior studies where we found that THg concentrations in breast feathers were poorly correlated with internal THg concentrations, such as blood, in avocets $\left(R^{2}=0.16\right)$, stilts $\left(R^{2}=0.37\right)$, and terns $\left(R^{2}=0.20\right)$, whereas THg concentrations in head feathers were more strongly correlated with internal THg concentrations in avocets $\left(R^{2}=0.76\right)$ and stilts $\left(R^{2}=0.64\right)$, but not terns $\left(R^{2}=0.14\right)$ (Eagles-Smith et al., 2008). Therefore, feather THg concentrations were useful for predicting THg concentrations in eggs only for those species where feather THg concentrations were correlated with internal $\mathrm{Hg}$ burdens. $\mathrm{Hg}$ concentrations in feathers represent the amount of $\mathrm{Hg}$ in the blood at the time of feather growth, and therefore interpretation of feather $\mathrm{Hg}$ concentrations depends on the timing of the most recent molt for the specific feather tract that was sampled (Bearhop et al., 2000; Braune and Gaskin, 1987; Furness et al., 1986; Thompson et al., 1998). Thus, a complete understanding of a species molt patterns and timing, or a strong correlation between THg concentrations in feathers and internal tissues, would be required in order to use feather THg concentrations to predict THg concentrations in eggs. For example, avocets molt their pale-gray winter head plumage immediately prior to breeding, to an orange-rufous plumage during the March through August breeding season (Ackerman et al., 2013a). Thus, head feathers may represent more recent exposure in avocets and may explain why THg concentrations in head feathers were better correlated to egg THg concentrations than breast feathers. However, Forster's terns also molt their head feathers in February through March prior to breeding, with their crown plumage turning from mottled white to black (McNicholl et al., 2001). Although tern head feather THg concentrations likely represented more recent contaminant exposure as it did in avocets, unlike avocets, tern head feathers were not related to egg THg concentrations. Feather THg concentrations can be most useful in bird species with extremely small home ranges where it is likely that internal THg concentrations do not change dramatically within an individual bird over time (Ackerman et al., 2012), like they often do in highly mobile bird species (Eagles-Smith et al., 2008) or individuals with rapidly changing physiology (Ackerman et al., 2011).

In addition to maternal transfer of contaminants to eggs, we found that THg and Se concentrations in tern eggs were positively correlated with THg and Se concentrations in their fathers (Figure 4). Because males and females exhibited similar relationships between body tissues and their eggs, this suggests that contaminant concentrations in males were strongly correlated with those in the females which laid the eggs. There are several mechanisms that could contribute to highly correlated contaminant concentrations between mates. Courtship feeding is common in Forster's terns, with the male often delivering prey to the female during pair formation, courtship, copulation, and incubation (McNicholl et al., 2001) at a prey delivery rate ranging from 0.5-1.3 fish per hour (Fraser, 1997). The highest rates of courtship feeding by male terns occurs prior to egg laying (Fraser, 1997; Nisbet, 1973), corresponding to the time when albumen synthesis occurs in eggs (Astheimer, 1986; Hobson, 1995). The vast majority of MeHg, but not necessarily Se, in eggs is within the albumen (Čobanová et al., 2011; Golubkina and Papazyan, 2006; Kennamer et al., 2005), and recent Hg acquired through the diet can be rapidly transferred to the eggs (Heinz et al., 2009a; Lewis and Furness, 1993). Thus, courtship feeding provides a mechanism whereby male foraging behavior can influence contaminant concentrations in their mates and eggs. Similar contaminant concentrations in a breeding pair may also 
be caused by mates foraging in similar areas and on similar prey. Because Hg concentrations in prey fish of Forster's terns can vary dramatically among adjacent wetlands (Eagles-Smith and Ackerman, 2014) and over short time periods (Eagles-Smith and Ackerman, 2009), the similar Hg concentrations in mates suggests that the pair's foraging behaviors were coordinated. Colonial breeding seabirds are thought to use social information to identify foraging areas (Thiebault et al., 2014; Ward and Zahavi, 1973), and tern mates may have shared foraging information with one another and employed similar foraging strategies. Although we have no direct evidence for this, other than their similar Hg and Se concentrations which can act as environmental tracers for diet, previously we found that space use by breeding Forster's terns did not differ between males and females (Bluso-Demers et al., 2008) and that incubation bouts by mates were similar between the sexes and coordinated (Bluso-Demers et al., 2010). Despite the strong correlation between THg and Se concentrations in tern eggs and their fathers, we would caution against extrapolating these male predictive equations to other species where mates' foraging behaviors may not be so tightly linked.

We estimated that incubating male terns had 21\% higher THg concentrations in their blood compared to incubating female terns at the same egg THg concentration. It is unclear whether this difference was caused solely by females depurating Hg into their eggs, but this difference was specifically for incubating parents shortly after egg-laying and accounted for overall differences in $\mathrm{Hg}$ concentrations among individuals with the inclusion of their egg THg concentrations in the model. Our value is very similar to Lewis et al.'s (1993) estimate that female herring gulls can excrete $24 \%$ more $\mathrm{Hg}$ than males because of their ability to transfer Hg into eggs.

In summary, we found that contaminant concentrations in eggs and parents were highly correlated, and contaminant concentrations in eggs can be predicted by contaminant concentrations in a female's internal tissues. We found similarly strong correlations between THg concentrations in eggs and THg and MeHg concentrations in the four internal tissues. The similarity in results among tissues and forms of $\mathrm{Hg}$ aligns with our prior studies that found strong correlations in Hg concentrations among internal tissues for birds (Eagles-Smith et al., 2008). We were able to develop equations to predict contaminant concentrations in eggs from each of the major tissues that are commonly sampled in bird studies, including blood (THg eqs 1-3), muscle (THg eqs 5-7), liver (THg eqs 8-10, MeHg eqs 11-13, Se eqs 23-25), and kidney (THg eqs 14-16, MeHg eqs 17-19). To illustrate the utility of these tissue conversion equations, we can use toxicity benchmarks that have been developed for different tissues and convert them into equivalent egg THg concentrations, and vice versa. For example, commonly used THg toxicity benchmarks are $3.0 \mu \mathrm{g} / \mathrm{g}$ ww for blood (Burgess and Meyer, 2008; Evers et al., 2008) and $8.5 \mu \mathrm{g} / \mathrm{g} \mathrm{dw}$ for liver (Eagles-Smith et al., 2009b). A maternal blood THg concentration of $3.0 \mu \mathrm{g} / \mathrm{g} \mathrm{ww}$ would result in her eggs having an average THg concentration of $1.40,1.26$, and $0.99 \mu \mathrm{g} / \mathrm{g}$ fww in terns, stilts, and avocets, respectively. Similarly, a maternal liver THg concentration of $8.5 \mu \mathrm{g} / \mathrm{g} \mathrm{dw}$ would result in her eggs having an average THg concentration of $0.75,0.57$, and $0.44 \mu \mathrm{g} / \mathrm{g}$ fww in terns, stilts, and avocets, respectively. These estimated egg THg concentrations align closely with toxicity benchmarks developed for eggs, which typically range from 0.6 to $1.0 \mu \mathrm{g} / \mathrm{g}$ fww (Braune et al., 2012; Heinz et al., 2009b; Kenow et al., 2011; Scheuhammer et al., 2007; Shore et al., 2011). In addition to predicting THg concentrations in eggs, these equations also can be used to estimate Hg concentrations in females based on THg concentration in eggs. For example, if the average THg concentration in a clutch of tern eggs was $1.0 \mu \mathrm{g} / \mathrm{g}$ fww, than this would correspond to the mother having THg concentrations of $2.0 \mu \mathrm{g} / \mathrm{g}$ ww in blood, $4.0 \mu \mathrm{g} / \mathrm{g} \mathrm{dw}$ in muscle, $11.8 \mu \mathrm{g} / \mathrm{g} \mathrm{dw}$ in liver, and $13.5 \mu \mathrm{g} / \mathrm{g} \mathrm{dw}$ in kidney. The predictive equations specific to the species of bird were necessary due to the significant species effect (different intercepts). However, because there were no interactions between species and internal Hg concentrations in females (same slopes), the general equation (eq 4) could be used to approximate THg concentrations in eggs from THg concentrations in mother's blood when no other 
reasonable maternal transfer model is available for a specific species. Caution should be used when applying this general equation because there are limited studies on maternal transfer in birds and it is unclear whether a general equation can be applied across taxa.

\section{Acknowledgments}

This research was funded by the CALFED Bay-Delta Program's Ecosystem Restoration Program with additional support from the U. S. Geological Survey's Ecosystems Mission Area and Contaminant Biology Program. We thank Sarah Stoner-Duncan, Terry Adelsbach, John Henderson, Cathy Johnson, Jill Bluso-Demers, Scott Demers, Joe Northrup, Angela Rex, Brooke Hill, Kristen Dybala, Stacy Moskal, Ross Wilming, Lindsay Dembosz, Emily Eppinger, Mychal Truwe, River Gates, Lani Stinson, Eli French, and Maliheh Nakhai for field assistance; Robin Keister and Brenda Lasorsa for lab analyses; and Julie Yee for statistical advice. We also thank Clyde Morris, Joy Albertson, Mendel Stewart, Joelle Buffa, Eric Mruz, Cheryl Strong, and the staff at the Don Edwards San Francisco Bay National Wildlife Refuge (U.S. Fish and Wildlife Service); John Krause and the staff of the Eden Landing Ecological Reserve (California Department of Fish and Wildlife); Tom Huffman, Larry Wyckoff, Carl Wilcox, Karen Taylor, and the staff of the Napa-Sonoma Marsh Wildlife Area (California Department of Fish and Wildlife); Lew Allen and the Can Duck Club; and Steve Schwarzbach, Tom Suchanek, John Takekawa, Keith Miles, and Tom Maurer for logistical support. The use of trade, product, or firm names in the publication is for descriptive purposes only and does not imply endorsement by the U.S. Government.

\section{References}

Ackerman, J.T., Eagles-Smith, C.A., 2010. Accuracy of egg flotation throughout incubation to determine embryo age and incubation day in waterbird nests. Condor 112, 438-446. doi:10.1525/cond.2010.090070

Ackerman, J.T., Eagles-Smith, C.A., 2009. Selenium bioaccumulation and body condition in shorebirds and terns breeding in San Francisco Bay, California, USA. Environ. Toxicol. Chem. 28, 21342141. doi:10.1897/09-101.1

Ackerman, J.T., Eagles-Smith, C.A., Herzog, M.P., 2011. Bird mercury concentrations change rapidly as chicks age: toxicological risk is highest at hatching and fledging. Environ. Sci. Technol. 45, 5418-5425. doi:10.1021/es200647g

Ackerman, J.T., Eagles-Smith, C.A., Takekawa, J.Y., Bluso, J.D., Adelsbach, T.L., 2008. Mercury concentrations in blood and feathers of prebreeding Forster's terns in relation to space use of San Francisco Bay, California, USA, habitats. Environ. Toxicol. Chem. 27, 897-908. doi:Doi 10.1897/07-230.1

Ackerman, J.T., Hartman, C.A., Herzog, M.P., Takekawa, J.Y., Robinson, J.A., Oring, L.W., Skorupa, J.P., Boettcher, R., 2013a. American Avocet (Recurvirostra americana), in: Poole, A. (Ed.), The Birds of North America Online. Cornell Lab of Ornithology, Ithaca, New York.

Ackerman, J.T., Herzog, M.P., Hartman, C.A., Takekawa, J.Y., 2014. Comparative reproductive biology of sympatric species: nest and chick survival of American avocets and black-necked stilts. J. Avian Biol. 45, 609-623. 
Ackerman, J.T., Herzog, M.P., Schwarzbach, S.E., 2013b. Methylmercury is the predominant form of mercury in bird eggs: a synthesis. Environ. Sci. Technol. 47, 2052-2060.

Ackerman, J.T., Overton, C.T., Casazza, M.L., Takekawa, J.Y., Eagles-Smith, C.A., Keister, R.A., Herzog, M.P., 2012. Does mercury contamination reduce body condition of endangered California clapper rails? Environ. Pollut. 162, 439-448. doi:10.1016/j.envpol.2011.12.004

Astheimer, L., 1986. Egg formation in Cassin’s Auklet. Auk 103, 682-693.

Bearhop, S., Ruxton, G.D., Furness, R.W., 2000. Dynamics of mercury in blood and feathers of greet skuas. Environ. Toxicol. Chem. 19, 1638-1643. doi:Doi 10.1897/15515028(2000)019<1638:Domiba>2.3.Co;2

Bluso, J.D., Ackerman, J.T., Takekawa, J.Y., Yee, J.L., 2006. Sexing Forster’s terns using morphometric measurements. Waterbirds 29, 512-517.

Bluso-Demers, J.D., Ackerman, J.T., Takekawa, J.Y., 2010. Colony attendance patterns by mated Forster's terns Sterna forsteri using an automated data-logging receiver system. Ardea 98, 59-65.

Bluso-Demers, J.D., Colwell, M.A., Takekawa, J.Y., Ackerman, J.T., Demers, S.A., 2008. Space use by Forster's terns breeding in South San Francisco Bay. Waterbirds 31, 357-364.

Bond, A.L., Hobson, K.A., Branfireun, B.A., 2015. Rapidly increasing methyl mercury in endangered ivory gull (Pagophila eburnea) feathers over a 130 year record. Proc. R. Soc. B 282. doi:10.1098/rspb.2015.0032

Brasso, R.L., Abdel Latif, M.K., Cristol, D.A., 2010. Relationship between laying sequence and mercury concentration in tree swallow eggs. Environ. Toxicol. Chem. 29, 1155-1159. doi:10.1002/etc. 144

Braune, B., Gaskin, D., 1987. Mercury levels in Bonaparte’s gulls (Larus philadelphia) during autumn molt in the Quoddy region, New Brunswick, Canada. Arch. Environ. Contam. Toxicol. 549, 539_ 549.

Braune, B.M., Scheuhammer, A.M., Crump, D., Jones, S., Porter, E., Bond, D., 2012. Toxicity of methylmercury injected into eggs of thick-billed murres and arctic terns. Ecotoxicology 21, 214352. doi:10.1007/s10646-012-0967-3

Burgess, N.M., Meyer, M.W., 2008. Methylmercury exposure associated with reduced productivity in common loons. Ecotoxicology 17, 83-91. doi:10.1007/s10646-007-0167-8

Čobanová, K., Petrovič, V., Mellen, M., Arpášova, H., Grešáková, L.L., Faix, Š., 2011. Effects of dietary form of selenium on its distribution in eggs. Biol. Trace Elem. Res. 144, 736-746. doi:10.1007/s12011-011-9125-7

Driscoll, C., Mason, R., Chan, H., Jacob, D., Pirrone, N., 2013. Mercury as a global pollutant: Sources, pathways, and effects. Environ. Sci. Technol. 47, 4967-4983. 
Eagles-Smith, C.A., Ackerman, J.T., 2014. Mercury bioaccumulation in estuarine wetland fishes: evaluating habitats and risk to coastal wildlife. Environ. Pollut. 193, 147-155.

Eagles-Smith, C.A., Ackerman, J.T., 2009. Rapid changes in small fish mercury concentrations in estuarine wetlands: Implications for wildlife risk and monitoring programs. Environ. Sci. Technol. 43, 8658-8664. doi:10.1021/es901400c

Eagles-Smith, C.A., Ackerman, J.T., Adelsbach, T.L., Takekawa, J.Y., Miles, a K., Keister, R.A., 2008. Mercury correlations among six tissues for four waterbird species breeding in San Francisco Bay, California, USA. Environ. Toxicol. Chem. 27, 2136-2153. doi:10.1897/08-038.1

Eagles-Smith, C.A., Ackerman, J.T., De La Cruz, S.E.W., Takekawa, J.Y., 2009a. Mercury bioaccumulation and risk to three waterbird foraging guilds is influenced by foraging ecology and breeding stage. Environ. Pollut. 157, 1993-2002. doi:10.1016/j.envpol.2009.03.030

Eagles-Smith, C.A., Ackerman, J.T., Yee, J., Adelsbach, T.L., 2009b. Mercury demethylation in waterbird livers: dose-response thresholds and differences among species. Environ. Toxicol. Chem. 28, 568-577. doi:10.1897/08-245.1

Evers, D.C., Savoy, L.J., DeSorbo, C.R., Yates, D.E., Hanson, W., Taylor, K.M., Siegel, L.S., Cooley, J.H., Bank, M.S., Major, A., Munney, K., Mower, B.F., Vogel, H.S., Schoch, N., Pokras, M., Goodale, M.W., Fair, J., 2008. Adverse effects from environmental mercury loads on breeding common loons. Ecotoxicology 17, 69-81. doi:10.1007/s10646-007-0168-7

Evers, D.C., Taylor, K.M., Major, A., Taylor, R.J., Poppenga, R.H., Scheuhammer, A.M., 2003. Common loon eggs as indicators of methylmercury availability in North America. Ecotoxicology 12, 69-81.

Fraser, G., 1997. Feeding ecology of Forster's terns on Lake Osakis, Minnesota. Colon. Waterbirds 20, 87-94.

Furness, R.W.W., Muirhead, S.J.J., Woodburn, M., 1986. Using bird feathers to measure mercury in the environment: relationships between mercury content and moult. Mar. Pollut. Bull. 17, 27-30. doi:Doi 10.1016/0025-326x(86)90801-5

Golubkina, N.A., Papazyan, T.T., 2006. Selenium distribution in eggs of avian species. Comp. Biochem. Physiol. Part B 145, 384-388. doi:10.1016/j.cbpb.2006.08.007

Hartman, C.A., Ackerman, J.T., Herring, G., Isanhart, J., Herzog, M., 2013. Marsh wrens as bioindicators of mercury in wetlands of Great Salt Lake: do blood and feathers reflect site-specific exposure risk to bird reproduction? Environ. Sci. Technol. 47, 6597-6605. doi:10.1021/es400910x

Heinz, G.H., Hoffman, D.J., Klimstra, J.D., Stebbins, K.R., 2010. Predicting mercury concentrations in mallard eggs from mercury in the diet or blood of adult females and from duckling down feathers. Environ. Toxicol. Chem. 29, 389-392. doi:10.1002/etc.50 
Heinz, G.H., Hoffman, D.J., Klimstra, J.D., Stebbins, K.R., 2009a. Rapid increases in mercury concentrations in the eggs of mallards fed methylmercury. Environ. Toxicol. Chem. 28, 19791981. doi:10.1897/09-060.1

Heinz, G.H., Hoffman, D.J., Klimstra, J.D., Stebbins, K.R., Kondrad, S.L., Erwin, C.A., 2009b. Species differences in the sensitivity of avian embryos to methylmercury. Arch. Environ. Contam. Toxicol. 56, 129-138. doi:10.1007/s00244-008-9160-3

Henny, C.J., Hill, E.F., Hoffman, D.J., Spalding, M.G., Grove, R.A., 2002. Nineteenth century mercury: hazard to wading birds and cormorants of the Carson River, Nevada. Ecotoxicology 11, 213-231.

Herring, G., Ackerman, J.T., Eagles-Smith, C.A., Adelsbach, T.L., Melancon, M.J., Stebbins, K.R., Hoffman, D.J., 2010. Organochlorine and PBDE concentrations in relation to cytochrome P450 activity in livers of Forster's terns (Sterna forsteri) and Caspian terns (Hydroprogne caspia), in San Francisco Bay, California. Arch. Environ. Contam. Toxicol. 58, 863-873. doi:10.1007/s00244009-9366-z

Hobson, K., 1995. Reconstructing avian diets using stable-carbon and nitrogen isotope analysis of egg components: patterns of isotopic fractionation and turnover. Condor 97, 752-762.

Hoffman, D.J., Eagles-Smith, C.A., Ackerman, J.T., Adelsbach, T.L., Stebbins, K.R., 2011. Oxidative stress response of Forster's terns (Sterna forsteri) and Caspian terns (Hydroprogne caspia) to mercury and selenium bioaccumulation in liver, kidney, and brain. Environ. Toxicol. Chem. 30, 920-929. doi:10.1002/etc.459

Kennamer, R.A., Stout, J.R., Jackson, B.P., Colwell, S. V., Brisbin, I.L., Burger, J., 2005. Mercury patterns in wood duck eggs from a contaminated reservoir in South Carolina, USA. Environ. Toxicol. Chem. 24, 1793-1800. doi:Doi 10.1897/03-661.1

Kenow, K.P., Meyer, M.W., Rossmann, R., Gendron-Fitzpatrick, A., Gray, B.R., 2011. Effects of injected methylmercury on the hatching of common loon (Gavia immer) eggs. Ecotoxicology 20, 1684-93. doi:10.1007/s10646-011-0743-9

Kenow, K.P., Meyer, M.W., Rossmann, R., Gray, B.R., Arts, M.T., 2015. Influence of in ovo mercury exposure, lake acidity, and other factors on common loon egg and chick quality in Wisconsin. Environ. Toxicol. Chem. 34, 1870-1880. doi:10.1002/etc.3001

Lewis, S., Furness, R., 1993. The role of eggs in mercury excretion by quail Coturnix coturnix and the implications for monitoring mercury pollution by analysis of feathers. Ecotoxicology 2, 55-64.

Lewis, S.A., Becker, P.H., Furness, R.W., 1993. Mercury levels in eggs, tissues, and feathers of herring gulls Larus argentatus from the German Wadden Sea Coast. Environ. Pollut. 80, 293-299.

McNicholl, M.K., Lowther, P.E., Hall, J.A., 2001. Forster’s Tern (Sterna forsteri), in: Poole, A. (Ed.), The Birds of North America Online. Cornell Lab of Ornithology, Ithaca, New York. 
604

605

606

607

608

609

610

611

612

613

614

615

616

617

618

619

620

621

622

623

624

625

626

627

628

629

630

631

632

633

634

635

636

Monteiro, L., Furness, R., Unit, A.O., Sciences, L., Monteiro, L., Furness, R., 1997. Accelerated increase in mercury contamination in North Atlantic mesopelagic food chains as indicated by time series of seabird feathers. Environ. Toxicol. Chem. 16, 2489-2493.

Nisbet, I., 1973. Courtship-feeding, egg-size and breeding success in common terns. Nature 241, 141142.

Ou, L., Varian-Ramos, C.W., Cristol, D.A., 2015. Effect of laying sequence on egg mercury in captive zebra finches: an interpretation considering individual variation. Environ. Toxicol. Chem. 34, 1787-1792. doi:10.1002/etc.2976

Rimmer, C.C., McFarland, K.P., Evers, D.C., Miller, E.K., Aubry, Y., Busby, D., Taylor, R.J., 2005. Mercury concentrations in Bicknell's thrush and other insectivorous passerines in montane forests of northeastern North America. Ecotoxicology 14, 223-240.

Robinson, J., Reed, J., Skorupa, J., Oring, L., 1999. Black-necked stilt (Himantopus mexicanus), in: Poole, A. (Ed.), The Birds of North America Online. Cornell Lab of Ornithology, Ithaca, New York.

Scheuhammer, A.M., Meyer, M.W., Sandheinrich, M.B., Murray, M.W., 2007. Effects of environmental methylmercury on the health of wild birds, mammals, and fish. Ambio 36, 12-18.

Seber, G.A.F., 1982. The estimation of animal abundance and related parameters, Second edition. Macmillan, New York.

Shore, R.F., Pereira, E., Walker, L.A., Thompson, D.R., 2011. Mercury in nonmarine birds and mammals, in: Beyer, W.N., Meador, J.P. (Eds.), Environmental Contaminants in Biota: Interpreting Tissue Concentrations, Second Edition. CRC Press, Boca Raton, pp. 609-626.

Thiebault, A., Mullers, R., Pistorius, P., Meza-Torres, M.A., Dubroca, L., Green, D., Tremblay, Y., 2014. From colony to first patch: processes of prey searching and social information in Cape Gannets. Auk 131, 595-609. doi:10.1642/AUK-13-209.1

Thompson, D.R., Bearhop, S., Speakman, J.R., Furness, R.W., 1998. Feathers as a means of monitoring mercury in seabirds: Insights from stable isotope analysis. Environ. Pollut. 101, 193-200.

U.S. Environmental Protection Agency, 2001. Method 1630, Methyl Mercury in Water by Distillation, Aqueous Ethylation, Purge and Trap, and Cold-Vapor Atomic Fluorescence Spectrometry; EPA821-R-01-020; Office of Water and Office of Science and Technology: Washington, D.C.

U.S. Environmental Protection Agency, 2000. Method 7473, Mercury in solids and solutions by thermal decomposition, amalgamation, and atomic absorption spectrophotometry. In Test Methods for Evaluating Solid Waste, Physical/Chemical Methods; SW 846, Update IVA; U.S. Government Printing Office. Washington, D.C. 
637

638

639

640

641

642

643

644

645
Ullrich, S.M., Tanton, T.W., Abdrashitova, S.A., 2001. Mercury in the aquatic environment: a review of factors affecting methylation. Crit. Rev. Environ. Sci. Technol. 31, 241-293. doi:10.1080/20016491089226

Ward, P., Zahavi, A., 1973. The importance of certain assemblages of birds as "information-centres" for food-finding. Ibis (Lond. 1859). 115, 517-534. doi:10.1111/j.1474-919X.1973.tb01990.x

Wiener, J.G., Krabbenhoft, D.P., Heinz, G.H., Scheuhammer, A.M., 2003. Ecotoxicology of mercury, in: Hoffman, D.J., Rattner, B.A., Burton, G.A.J., Cairns, J.J. (Eds.), Handbook of Ecotoxicology, Second Edition. CRC Press LCC, Boca Raton, Florida, pp. 409-463. 


\section{Figures}

647 Figure 1. Total mercury (THg) concentrations in eggs were highly correlated with the mother's THg 648 and methylmercury (MeHg) concentrations in (a) blood, (b) muscle, (c) liver (THg), (d) liver (MeHg), 649 (e) kidney (THg), and (f) kidney (MeHg) for three species of waterbirds (American Avocets: red circles, 650 black-necked stilts: orange squares, Forster's terns: blue triangles) nesting in San Francisco Bay, 651 California during 2005-2006. Y-axis values are geometric mean THg concentrations for each clutch, 652 and the error bars represent the minimum and maximum THg concentration for individual eggs within 653 the clutch. The solid regression lines are the model-predicted THg concentration in bird eggs, based on $654 \mathrm{THg}$ and MeHg concentrations in each tissue. Equations are available in the Results section.

655

656 
657

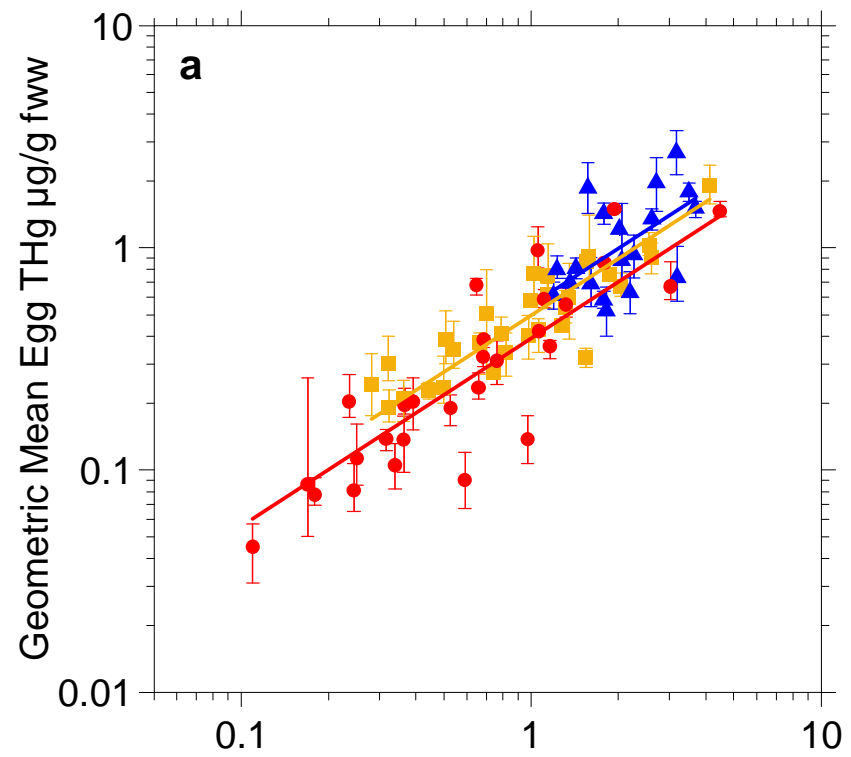

Female Blood THg $\mu \mathrm{g} / \mathrm{g}$ ww
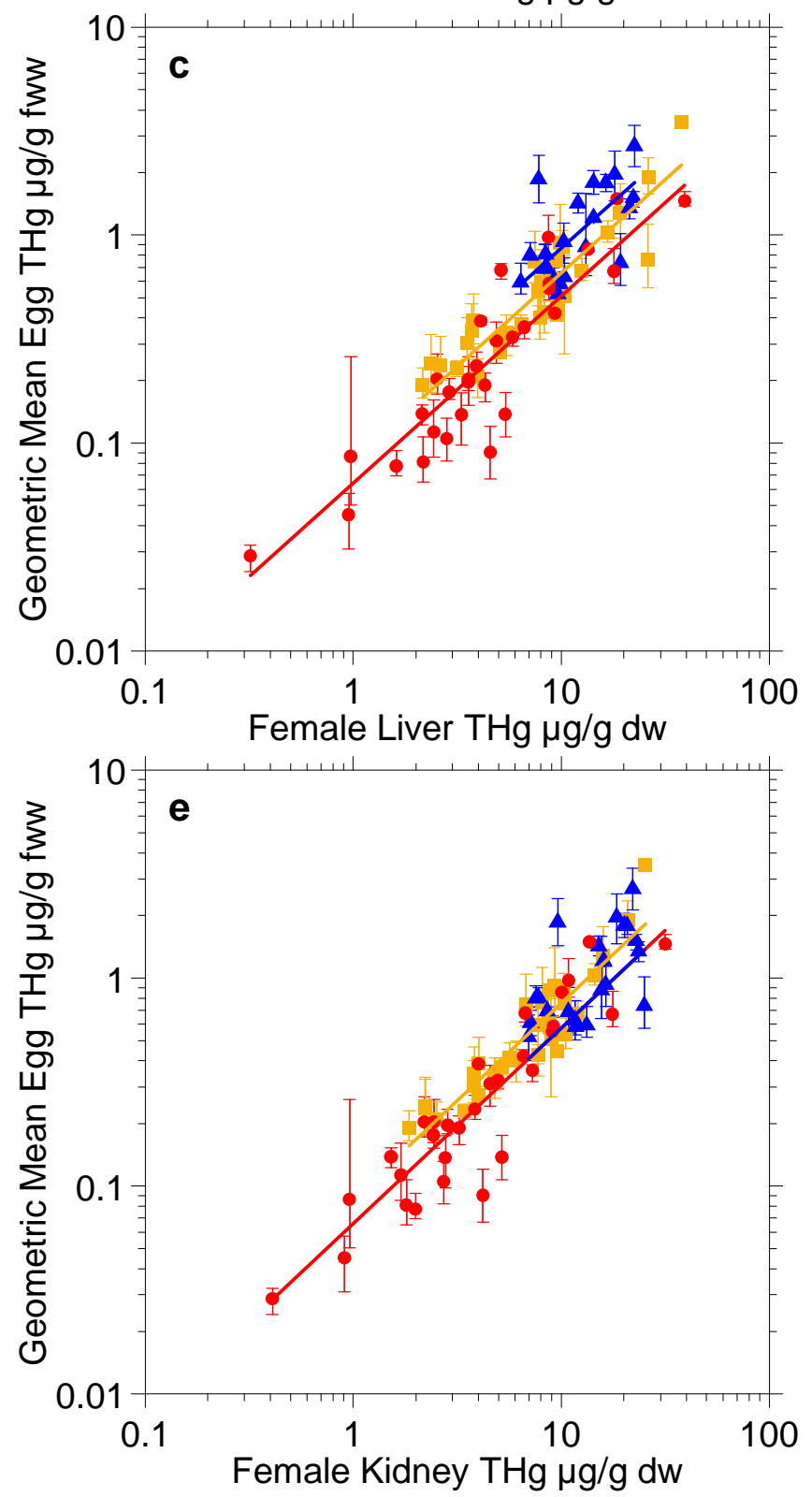
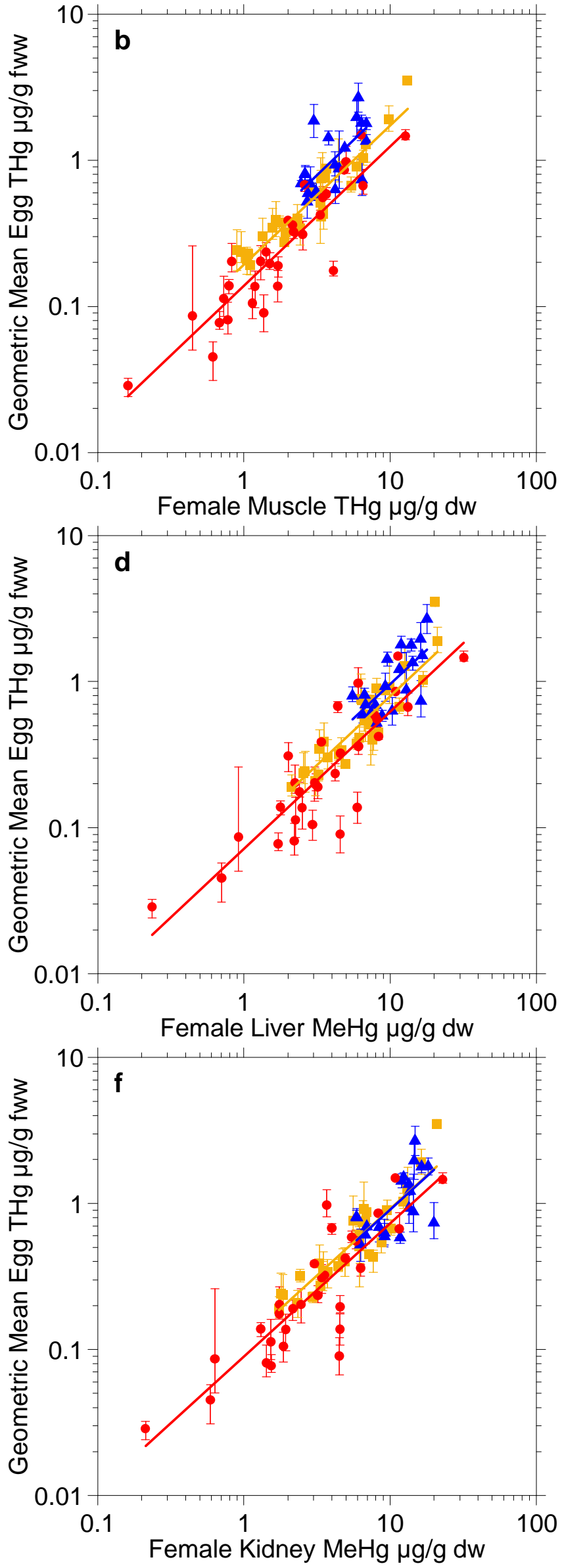
658

659

660

661

662

663

664

665

Figure 2. Total mercury (THg) concentrations in eggs in relation to the mother's THg concentrations in (a) head feathers and (b) breast feathers for three species of waterbirds (American Avocets: red circles, black-necked stilts: orange squares, Forster's terns: blue triangles) nesting in San Francisco Bay, California during 2005-2006. Y-axis values are geometric mean THg concentrations for each clutch, and the error bars represent the minimum and maximum THg concentration for individual eggs within the clutch. The solid regression lines are the model-predicted THg concentration in bird eggs, based on THg concentrations in feathers. Equations are available in the Results section.
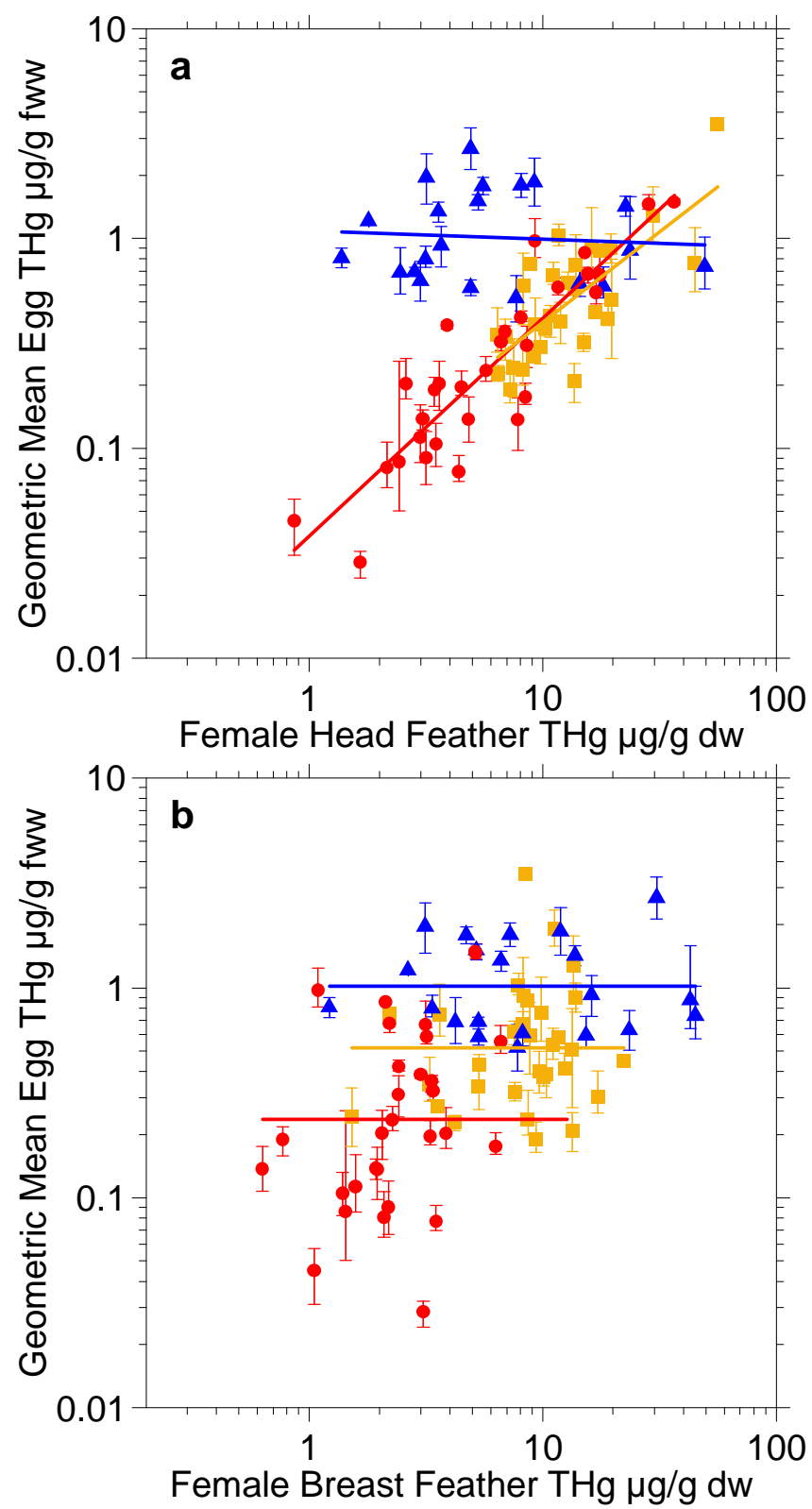
667 Figure 3. Selenium (Se) concentrations in eggs were correlated with Se concentrations in the mother's 668 liver for three species of waterbirds (American Avocets: red circles, black-necked stilts: orange squares, 669 Forster's terns: blue triangles) nesting in San Francisco Bay, California during 2005-2006. Y-axis 670 values are geometric mean Se concentrations for each clutch, and the error bars represent the minimum 671 and maximum Se concentration for individual eggs within the clutch. The solid regression lines are the 672 model-predicted Se concentration in bird eggs, based on Se concentrations in liver. Equations are 673 available in the Results section.

674

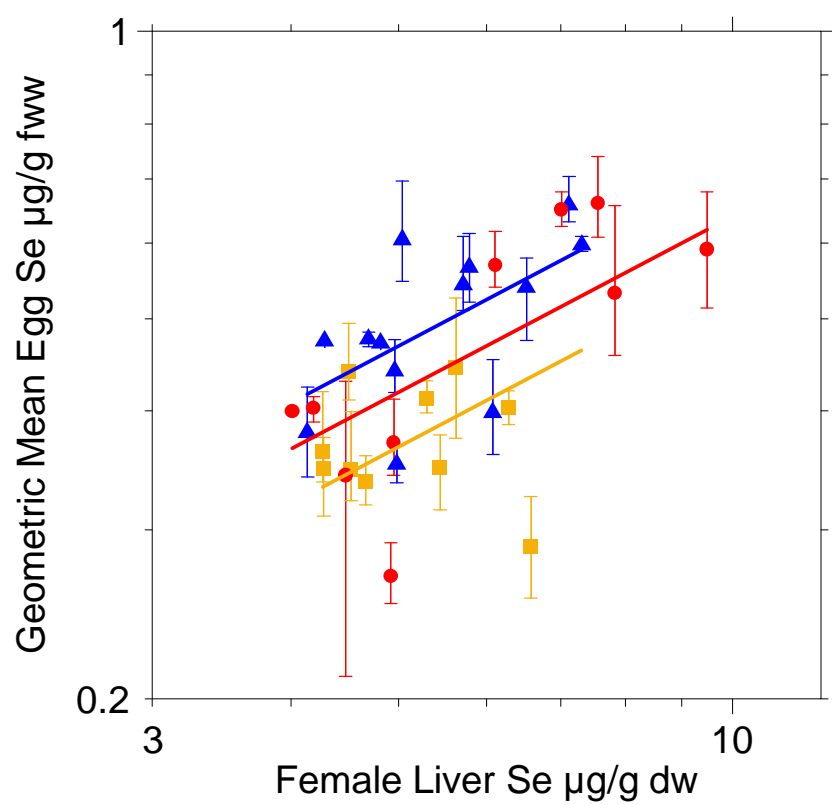


676

677

678

679

680

681

682

683

684

685

Figure 4. (a) Total mercury (THg) concentrations in eggs were correlated with both the mother's (solid blue triangle) and father's (open triangle) THg concentration in blood for Forster's terns nesting in San Francisco Bay, California during 2005-2006. (b) Selenium (Se) concentrations in eggs also were correlated with both the mother's (solid blue triangle) and father's (open triangle) Se concentration in liver for Forster's terns. Y-axis values are geometric mean contaminant concentrations for each clutch, and the error bars represent the minimum and maximum contaminant concentration for individual eggs within the clutch. The solid regression lines are the model-predicted contaminant concentration in bird eggs, based on contaminant concentrations in the parent's (a) blood and (b) liver. Equations are available in the Results section.
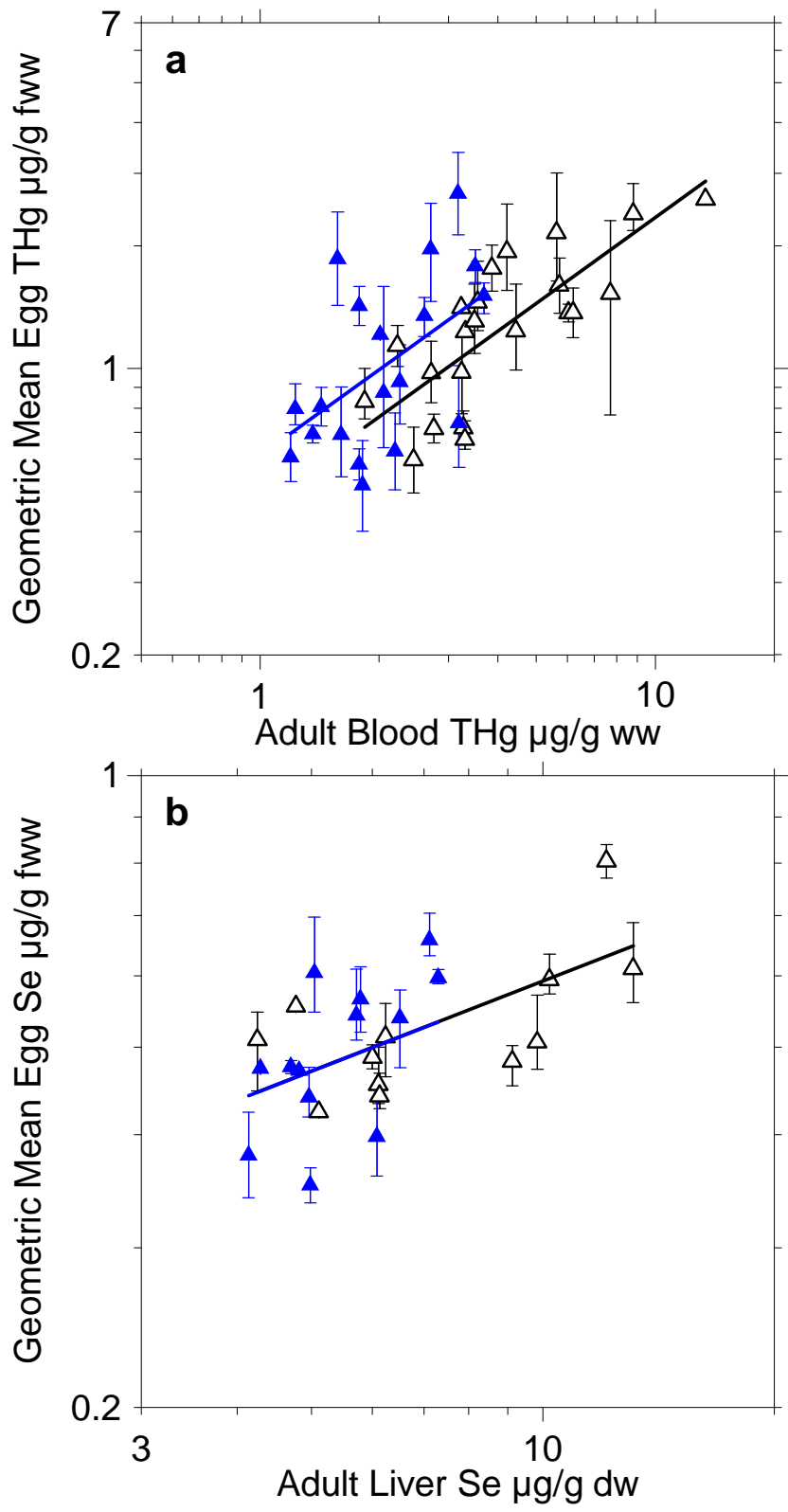